\title{
積層ゴム支承被覆ゴムの長期劣化特性に関する実験的研究 - 物理特性の変化一 \\ AN EXPERIMENTAL STUDY ON DURABILITY OF COVERING RUBBER APPLIED TO RUBBER BEARINGS
}

- Change of mechanical properties -

\author{
濱口弘樹*，長谷川 完**，大武義人*** \\ Hiroki HAMAGUCHI, Tamotsu HASEGAWA and Yoshito OHTAKE
}

\begin{abstract}
Aging effects of oxygen and water / saltwater on mechanical properties of two types of covering rubbers for isolation rubber bearings were experimentally studied. Rubber A (natural rubber) and Rubber B (synthetic rubber) were selected for the testing. Accelerated aging test corresponding to 80 years, water / saltwater cyclic spray test for 60 days, and the combination of the two tests were conducted for the both materials. Considering the configuration and the environmental condition of rubber bearings, rubber blocks, not dumbbell specimens, were chosen and exposed to the above deterioration factors. From the mechanical properties of dumbbell specimens cut out from the deteriorated rubber blocks, it became clear that oxidation affected the both specimens much larger than water / saltwater and that covering rubber was effective for protecting rubber bearings from those deterioration factors.
\end{abstract}

Keywords : Rubber bearing, Covering rubber, Aging effect, Durability, Oxidative deterioration, Saltwater deterioration 積層ゴム支承, 被覆ゴム，経年変化，耐久性，酸化劣化，塩水劣化

1. はじめに

免震建物は地震エネルギーの大半を免震部材で吸収する構造形式 であり，免震部材の特性が建物全体の地震応答特性に及ぼす影響が 極めて大きい。このため免震部材は，設計時の想定を超える特性変 化や損傷などが生じた場合に取り替えることができるよう配慮され ている。一方，取り替えに要する労力等が多大であることから，免 震部材には建物の供用期間と同等以上の長期間に渡って安定した性 能を維持することも期待されている。

免震部材の中で最も一般的な積層ゴム支承は，有機高分子材料で あるゴムを主要構成材料とすることから, 数十年に渡って継続使用 されることによる物理特性の経年変化を定量的に把握することが重 要である。こうした観点から, 長期間に渡って実際に使用されたゴ ム材料の経年変化に関する調查が多数行われている。例えば，オー ストラリアの鉄道用高架橋で約 100 年間使用された防振ゴムパッド の調查によると, 表面部はゴムが硬化して亀裂を生じるなどの劣化 が見られたが, 表面から 2〜 $5 \mathrm{~mm}$ 以上内部ではゴムの品質低下は認 められなかった 1)。また, イギリスの橋梁で約 40 年間使用された天 然ゴム（Natural Rubber，以下 NR）系積層ゴム支承を調查した結 果, 表面から深さ約 $50 \mathrm{~mm}$ までは表面に近いほどゴム硬度や $100 \%$ 引張応力が内部に比べて大きく，それより内部ではこれらの物理特
性がほぼ一定となる分布形となっていた 2)。この分布は主に空気中 の酸素がゴム表面から内部に向かって拡散浸透していく過程で生じ たものと考えられている。また，日本国内の免震建物で約 20 年間 使用された積層ゴム支承の調查によると，内部の NR は硬度，引張 特性，せん断特性がほとんど変化しておらず, Ethylene-PropyleneDiene terpolymer（以下 EPDM）系合成被覆ゴムが内部 NR への 酸素の拡散浸透を防止したためであると推測されている ${ }^{3)}$

定性的には，内部でもゴムに微量に含まれる酸素による分子結合 の切断と再結合などのため分子構造は変化する。ただし，その影響 は表面部分に比べてごく僅かであるとされている4),5)。

以上の知見より，積層ゴム支承の経年変化は主に外部劣化因子に 曝される表面から内部に向かって進行していくが，顕著な変化は表 面の数〜数十 $\mathrm{mm}$ 以内に留まるものと考えられる。

一方，設置場所や使用期間などの個別の条件を排し，積層ゴム支 承用ゴム材料の長期劣化特性を定量的に評価した研究は多くない。 伊藤ら ${ }^{6)}$ は橋梁支承用ゴムに酸素 (熱老化), オゾン，低温オゾン， 光, 塩水, 酸性雨の各因子を付与し, 物理特性の変化を調査してい る。また，被覆ゴムに用いられる EPDM 系合成ゴムに酸素（熱老 化), 各種薬品, 湿度を付与する実験の結果も報告されている7)。し かし，これらの研究では JIS3 号ダンベル試験片に直接劣化因子を

\footnotetext{
* (株竹中工務店技術研究所 振動制御グループ長・修士 (工学)

** (株竹中工務店技術研究所 主任研究員

*** (一財) 化学物質評価研究機構 高分子技術センター所長・博士(工学)
}

Structural Dynamics Group Leader, Research and Development Institute, Takenaka Corporation, M.Eng.

Chief Researcher, Research and Development Institute, Takenaka Corporation

General Manager, Polymer Technology Center, Chemicals Evaluation and Research Institute, Japan, Dr.Eng. 
付与している。ダンベル試験片は厚さ $2 \mathrm{~mm}$ と薄く, かつ体積に対 して表面積が大きく, 外部劣化因子は試験片の全方向から内部に向 かって浸透していく。よって, 表面から内部に向かって一方向に分 布形を形成すると考えられる積層ゴム支承の劣化過程に鑑みて, 物 理特性変化を過大に評価している恐れがある。

一般に, 積層ゴム支承は外周部を厚さ $8 \sim 10 \mathrm{~mm}$ 程度のゴムで被 覆されている。従って, 被覆ゴムが長期に渡って外部劣化因子を遮 断し続けることができるならば，積層ゴム支承に大きな経年変化を 生じることはないと考えることができる。本研究では, 積層ゴム支 承の被覆ゴム材料について, 外部劣化因子が表面一方向のみから作 用する積層ゴム支承の形状および設置環境条件を考慮した実験によ り，建物供用期間に相当する経年後の劣化特性を評価する。

\section{2. 被覆ゴムの外部劣化因子}

\section{1 外部劣化因子の抽出}

ゴムの物理特性に変化を及ぼす要因は多岐に渡るが, 主な因子と して, 熱, 酸素, オゾン, 紫外線, 水/塩水などが挙げられる 4),5)。 ゴムは，概ね $100^{\circ} \mathrm{C}$ 以下の熱に対しては酸化劣化が促進されるの み 4)であるが，より高温になると温度上昇とともに次第に軟化，液 化し, 最終的には $200^{\circ} \mathrm{C}$ 程度で熱分解して気体となる5)。通常, 免 震層が $100^{\circ} \mathrm{C}$ 超える高温となる状況は考えにくいため, 熱は本研 究の検討対象外とする。オゾンは空気中の酸素に紫外線が作用する ことによって発生する。強い酸化力を持つため, ゴム表面に亀裂を 生じる原因となる。田中ら 8 によると, 日本国内における空気中の オゾン濃度は概ね $1 \mathrm{pphm}$ (parts per hundred million, 1 億分の 1 ) から日中の紫外線量の多い時間帯で $10 \mathrm{pphm}$ 程度である。免震層内 の空気は直射日光による紫外線の作用を受けることがないため，才 ゾン濃度は数 pphm 以下で安定していると考えられる。伊藤ら ${ }^{6}$ は NR およびクロロプレンゴム（Chloroprene Rubber, 以下 CR）の JIS3 号ダンベル試験片を用い, JIS K 6259 「加硫ゴムのオゾン劣 化試験方法」に則ってオゾン濃度 $5 \mathrm{pphm}$, 温度 $40^{\circ} \mathrm{C} /-30^{\circ} \mathrm{C}, 64$ 日間の劣化促進試験を行っている。この結果, 両ゴムとも $100 \%$ 引 張応力が $10 \sim 20 \%$ 程度増加したが, 目視観察によると劣化付与後の 試験片にクラックの発生は認められなかった。従って, オゾンおよ び紫外線についても本研究の対象外とする。

以上の知見を踏まえ, 本研究では被覆ゴムの外部劣化因子として, 酸素および水/塩水を取り上げることとする。

\section{2 酸素}

空気に接触する被覆ゴム表面では酸素が連続的に供給され, 酸化 劣化が常時進行するとともに, 酸素が積層ゴム支承の内部に向かっ て拡散浸透していく。被覆ゴムの厚さや酸素の拡散浸透速度によっ ては, 建物供用期間内に空気中の酸素が内部ゴムにまで達し, 酸化 劣化を引き起こすこととなる。

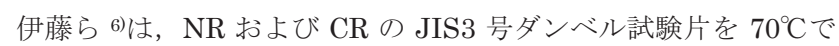
最大 6,144 時間まで加熱して酸化劣化を促進し, 物理特性の経年変 化を調査している。実験に用いられた NRの場合, この加熱条件は 東京の平均気温 $15.9^{\circ} \mathrm{C}$ で最大 384 年間の酸化劣化を付与したことに 相当する。この結果, $\mathrm{NR}, \mathrm{CR}$ ともに引張応力の増加, 引張強さお よび切断時伸びの低下が加熱時間とともに対数関数状に進行し, 3,072 時間経過以降はほぼ安定した。6,144 時間経過後の物理特性
変化は, 両ゴムとも 100\%引張応力が初期值の約 2.5 倍, 破断伸び が NR で 80\%低下，CR で 54\%低下となった。

\section{3 水 $/$ 塩水}

ゴムに配合される添加剤や充填剤の中に水との親和性が高い材料 が含まれると，ゴムが吸水膨潤する恐れがある5)。例えば山田ら9) は, 水道管のシーリング材に用いられる EPDM は水道水に接して いるらちに補強材として配合される吸水性の高いカーボンブラック が水を吸着し, ゴム内の老化防止剤の水中への溶出を促進し, 著し い劣化を起こして漏水事故となる場合があることを指摘している。 さらに, 水道水中に残留塩素が含まれる場合は, 水分吸着と劣化が 相乗的に生じるとの中村ら ${ }^{10)}$ の報告もある。高湿度の免震層では被 覆ゴム表面が結露しやすく，また海岸沿いの建物では飛沫塩分の影 響も考えられることから，水／塩水が被覆ゴムの劣化に及ぼす影響 を評価しておくことが望ましい。

伊藤ら ${ }^{6)}$ は, NR および CR の JIS3 号ダンベル試験片の耐塩水性 についても検討を行っている。JIS K 5600-7-9「塗料一般試験方法 サイクル D」（Fig. 1 参照）に則った塩水サイクル噴霧を 60 日間に 渡って施し, 物理特性の変化を調查した結果, 両ゴムとも $100 \%$ 引 張応力が約 $20 \%$ 増加した。被覆ゴムに使用される EPDM 系合成ゴ ムを塩水中に長時間浸漬して物理特性の変化を調查した事例 7)では, JIS3 号ダンベル試験片を濃度 5\%の塩水中に 3 週間浸漬した結果, $100 \%$ 引張応力が約 $10 \%$ 低下, 切断時伸びが約 $3 \%$ 増加, 引張強さが 約 $10 \%$ 低下した。なお，両文献で $100 \%$ 引張応力の変化が逆の傾向 となっており, 調査の目的に応じて試験方法を適切に選択すること の重要性が示唆される。

\section{3. 実験方法}

\section{1 試験体概要}

被覆ゴムの酸化劣化, 水/塩水劣化, および両因子の複合劣化の 度合いを定量的に評価する目的で実験を行った。表面から内部に向 かって一方向に劣化が進行する積層ゴム支承の形状および設置環境 条件を模擬するため, 直方体形状の厚肉ゴムブロック試験体に外部 劣化因子を付与寸ることとし, 実際に積層ゴム支承の被覆に使用さ れている 2 種類のゴム材料を用いたブロック試験体を製作した。両 試験体の形状寸法と数量を Table1 に，外観をPhoto1 に示す。

Table1 Outline of rubber blocks

\begin{tabular}{|c|c|c|c|}
\hline 名称 & 形状寸法（mm） & 数量 & 配合（重量含有率） \\
\hline $\begin{array}{l}\text { ゴム } A \\
\text { (NR 系) }\end{array}$ & $\square-150 \times 150 \times 22$ & 10 体 & $\begin{array}{l}\mathrm{NR}(59.7 \%), \text { カーボンブラック }(18.4 \%), \\
\text { アセ卜抽出物 }(18.0 \%), \text { 灰分 }(3.9 \%)\end{array}$ \\
\hline $\begin{array}{c}\text { ゴム B } \\
(\mathrm{EPDM} \text { 系) }\end{array}$ & $\square-150 \times 150 \times 26$ & 10 体 & $\begin{array}{l}\mathrm{EPDM} \cdot \mathrm{NR} \text { 合成材 }(53.8 \%), \\
\text { カーボンブラック }(21.6 \%), \\
\text { アセトン抽出物 }(21.6 \%), \text { 灰分 }(3.0 \%)\end{array}$ \\
\hline
\end{tabular}

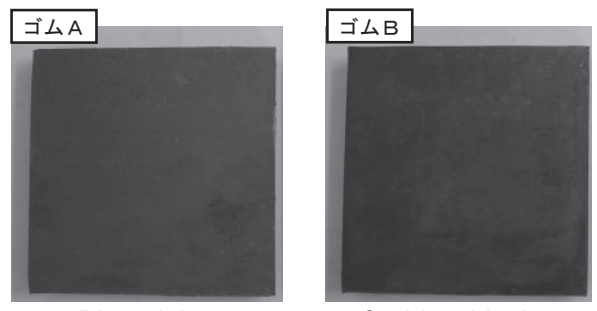

Photo1 Appearances of rubber blocks 
実験に先立って両ゴムの組成分析を行い, ゴム材, 充填剤および 添加剤の配合率を調査した。結果を Table1にあわせて示す。ゴム A は NR を主材料としてカーボンブラックが $18 \%$ 程度充填され, ゴム B は EPDM と NR の合成材を主材料とし, カーボンブラックが $22 \%$ 程度充填されている。また, アセトン抽出物のポリマー定性分析に より, 鉱物油, パルミチン酸, ステアリン酸, 各種の老化防止剂な どの添加剤が含まれていることが分かった。

\section{2 外部劣化因子の付与}

ゴム A，ゴム B とも Table 2 に示寸通り，物理特性の初期值測定 用の 1 体を除く 9 体のゴムブロック試験体に対して, 1 体ずつ異な る条件で外部劣化因子を付与した。

\section{2 .1 水 $/$ 塩水劣化}

水/塩水に対するゴム劣化特性の評価方法は確立されていない。 積層ゴム支承は結露などによって一時的に表面に水分が付着するこ とは想定されるものの, 免震層の浸水などにより長期に渡って水 $/$ 塩水に浸漬されることは考えにくい。本研究では, 積層ゴム支承の 設置環境条件を考慮する主旨に鑑夕て, 断続的に水/塩水を試験体 表面に噴霧する方法を採用することとした。付与方法は伊藤ら ${ }^{6}$ 同 様, 鋼材塗膜の耐塩水性評価方法である JIS K 5600-7-9 サイクル D（Fig.1）に準じた。塩化ナトリウム濃度は $50 \pm 10 \mathrm{~g} / 1$ である。水 劣化については, 塩水に代わって純水を用いたことを除き, 塩水劣 化と同一条件である。噴霧サイクル数も伊藤ら ${ }^{6)}$ に倣い, 120 回 (30 日間）および 240 回（60日間）とし，ゴム A, ゴム B とも劣化条 件毎に 1 体, 計 4 体のゴムブロック試験体を使用した。複合サイク ル試験機による水／塩水サイクル噴霧方法の概要を Fig.2 に示寸。

\section{2 .2 酸化劣化}

酸化劣化は, JIS K 6257 「加硫ゴム及び熱可塑性ゴム-熱老化特性 の求め方」に基づき，ゴムブロック試験体を加熱することによって 促進付与した。加熱条件は(1)式に示寸アレニウス則により算定した。

$$
\ln \frac{\mathrm{t}_{0}}{\mathrm{t}_{\mathrm{y}}}=\frac{\mathrm{E}_{\mathrm{a}}}{\mathrm{R}}\left(\frac{1}{\mathrm{~T}_{0}}-\frac{1}{\mathrm{~T}_{\mathrm{y}}}\right)
$$

ここで, $\mathrm{T}_{0}$ : 設置環境温度 $(\mathrm{K}), \mathrm{t}_{0}$ : 設置環境温度における時間, $\mathrm{T}_{\mathrm{y}}$ : 加熱温度 $(\mathrm{K}), \mathrm{t}_{\mathrm{y}}$ : 加熱温度における時間, $\mathrm{R}$ : 気体定数 $(8.314 \mathrm{~J} / \mathrm{mol} / \mathrm{K})$, $\mathrm{E}_{\mathrm{a}}$ : ゴムの熱劣化に対する活性化エネルギー（ゴム A : $97 \mathrm{~kJ} / \mathrm{mol}$, ゴム B : $85 \mathrm{~kJ} / \mathrm{mol}$ ) である。本研究では積層ゴム支承を $20^{\circ} \mathrm{C}$ 環 境下で 80 年間使用するものと想定した。加熱温度を $85^{\circ} \mathrm{C}$ に設定す ると，(1)式に $\mathrm{T}_{0}=(20+273) \mathrm{K}, \mathrm{t}_{0}=(80 \times 365)$ 日, $\mathrm{T}_{\mathrm{y}}=(85+273) \mathrm{K}$ を代 入して $t_{\mathrm{y}}$ にいて展開した(2)式より, 加熱時間はゴム $\mathrm{A} か ゙ 21$ 日間, ゴム $\mathrm{B}$ が 52 日間と定まる。両ゴムともに, 酸化劣化の影響を評価 するための 1 体, および次節で述べる酸素と水/塩水の複合劣化を 評価するための 4 体, の計 5 体のゴムブロック試験体を上記条件で 加熱した。

$$
\mathrm{t}_{\mathrm{y}}=80 \times 365 \times \exp \left\{\frac{\mathrm{E}_{\mathrm{a}} \times 10^{3}}{8.314}\left(\frac{1}{85+273}-\frac{1}{20+273}\right)\right\}
$$

\subsection{3 酸素と水 $/$ 塩水の複合劣化}

新品状態のゴムと 80 年相当の酸化劣化後のゴムの耐水/而塩水 性を比較することを目的として，加熱促進を終えたゴム A，ゴム B 各 5 体のゴムブロック試験体のうち各 4 体について, さらに 3.2 .1
節に示した方法で水／塩水サイクル噴霧を施した。

\section{3 物理特性の測定}

ゴムは, 分子鎖切断などにより化学構造の変化が生じると, 必然 的に物理特性にも影響を及ぼす。そこで, 以下に示す方法で物理特 性の初期值と劣化後の值を測定し, それらの比較によりゴムの劣化 度を評価することとした。

物理特性を測定するための試験片作成手順を Fig. 3 に示す。両ゴ

Table2 Deterioration conditions (common to Rubber A and B)

\begin{tabular}{|c|l|c|}
\hline No. & \multicolumn{1}{|c|}{ 劣化条件 } & 略号 \\
\hline \hline 1 & 劣化因子付与せず (物理特性の初期值測定用) & INIT \\
\hline 2 & 純水サイクル噴霧 120 回 & PW1 \\
\hline 3 & 純水サイクル噴霧 240 回 & PW2 \\
\hline 4 & 塩水サイクル噴霧 120 回 & SW1 \\
\hline 5 & 塩水サイクル噴霧 240 回 & SW2 \\
\hline 6 & 80 年相当酸化劣化 & AGED \\
\hline 7 & 80 年相当酸化劣化 $\rightarrow$ 純水サイクル噴霧 120 回 & AGPW1 \\
\hline 8 & 80 年相当酸化劣化 $\rightarrow$ 純水サイクル噴霧 240 回 & AGPW2 \\
\hline 9 & 80 年相当酸化劣化 $\rightarrow$ 塩水サイクル噴霧 120 回 & AGSW1 \\
\hline 10 & 80 年相当酸化劣化 $\rightarrow$ 塩水サイクル噴霧 240 回 & AGSW2 \\
\hline
\end{tabular}

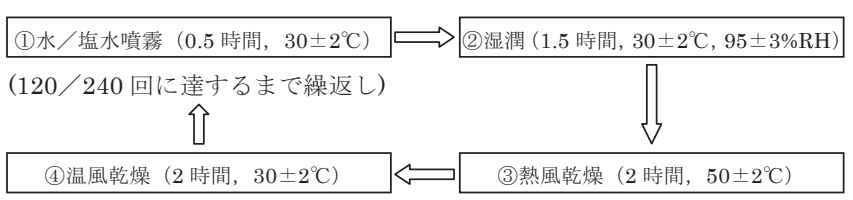

Fig.1 Procedure of water/saltwater cyclic spray

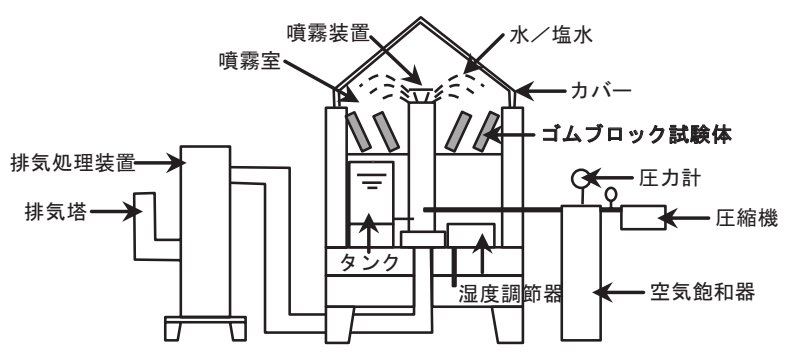

Fig.2 Method of water/saltwater cyclic spray

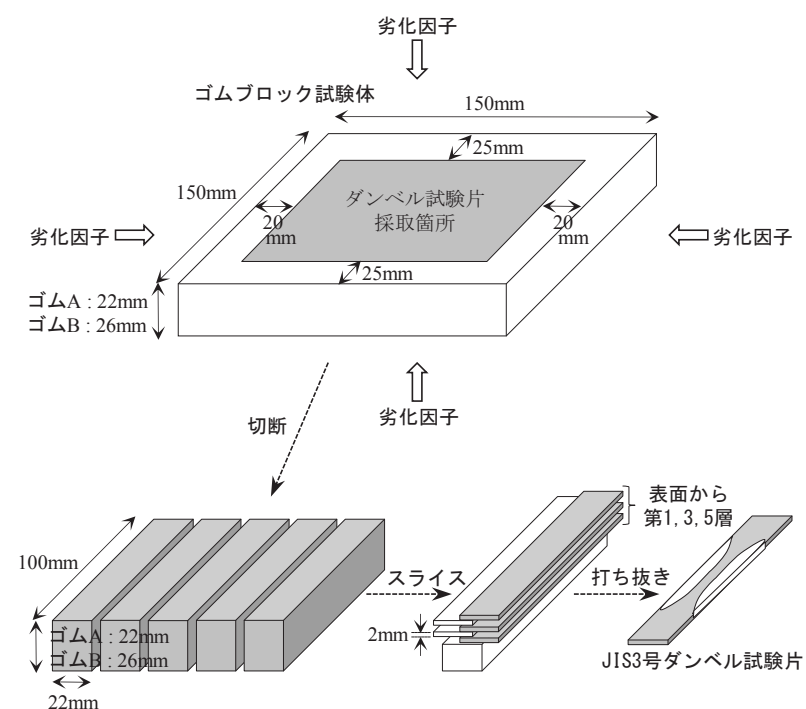

Fig.3 Procedure of cutting rubber blocks into dumbbell specimens 
ムとも全 10 体のゴムブロック試験体について, まず側面からの外 部劣化因子の影響を取り除くため外周部を切除した。次に中央部を 5 体のブロックに切り分け, 各ブロックを表面から順に $2 \mathrm{~mm}$ 厚さ のシート状に 5 層, 深さ $10 \mathrm{~mm}$ 位置までスライスした。このうち表 面から数えて第 $1 ， 3 ， 5$ 層のシートより JIS3 号ダンベル試験片を 打ち抜いた。

得られた全ダンベル試験片の国際ゴム硬さを測定した後, JIS K $6251 「$ 加硫ゴム及び熱可塑性ゴム-引張特性の求め方」に則って引 張試験を行い, 100\%引張応力, 引張強さを測定した。ただし, 国際 ゴム硬さは值が 1 刻みと測定精度が高くないこと, 引張強さは被覆 ゴムに要求されない破断時の終局特性であること, から本研究にお いては $100 \%$ 引張応力をゴム劣化度の主要な評価指標と位置付ける。

\section{4. 実験結果}

\section{1 試験体表面の外観}

被覆ゴムの主要な役割は，外部劣化因子の積層ゴム本体内への侵 入防止である。そこでまず，劣化因子の付与を終えたゴムブロック 試験体全数について, 目視による表面の観察を行った。一例として, 塩水サイクル噴霧 120 回終了直後の試験体 SW1 の外観を Photo2 に示す。特にゴム B において塩分が析出したことによる污れが現れ ているが，いずれの試験体にもゴム表面に亀裂発生などの有意な変 化は確認されなかった。

\section{2 ゴム $\mathrm{A}$ (NR 系) の物理特性変化}

水劣化, 酸化劣化および両因子の複合劣化を付与したことによる 物理特性の初期值からの変化を Fig.4 に示寸。図中の○は同一層の
ダンベル試験片 5 本の測定結果の中央值，上下端のーはそれぞれ最 大值および最小值を表す。

国際ゴム硬さの初期值は第 1 層から第 5 層までほぼ一定の值とな っている。水劣化を付与すると, 層によらず概ね噴霧サイクル数に 伴って硬さが増し, その増加度合いは表面に近いほど大きくなった。 酸化劣化を付与寸ると, 第 3,5 層では初期值に対して硬さが増し た一方，第 1 層は逆に軟化する結果となった。酸化劣化後のゴムに 水劣化を施すと, 初期状態からの変化と同様に噴霧サイクル数に伴 って硬さが増したが，層による有意な差は見られなかった。また全 体的に, 全層とも酸化劣化による硬さの変化が水劣化による変化に 比べて顕著に現れた。

$100 \%$ 引張応力も国際ゴム硬さと同様の傾向が見られる。初期值は 層によらずほぼ一定であった。全層とも酸化劣化による応力の変化 が水劣化による変化に比べて大きく, かつ酸化劣化によって第 3,5 層では応力が増加したのに対し，第 1 層は低下している。

引張強さには，硬さ，100\%引張応力とは異なる傾向が見られる。 ゴム破断時の終局特性であるがゆえに結果のばらつきが他の指標に
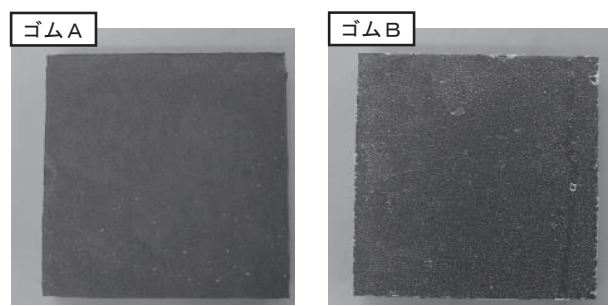

Photo2 Appearances of SW1 rubber blocks after deterioration
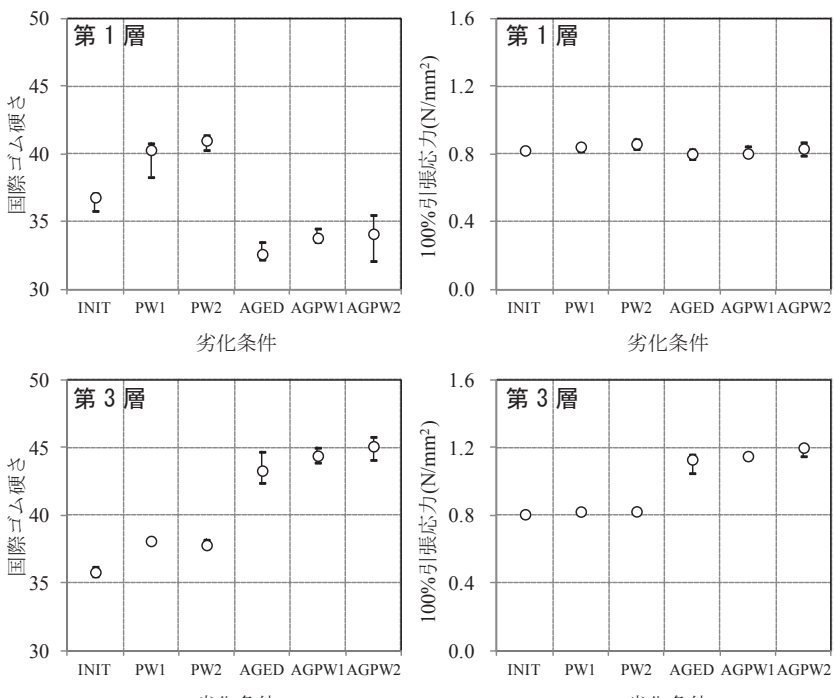

劣化条件

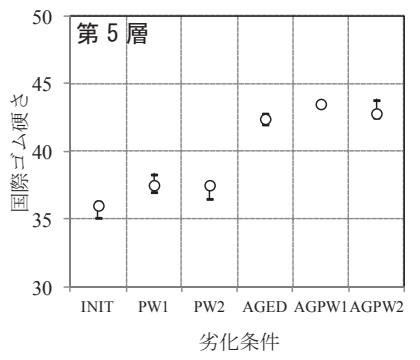

国際ゴム硬さ

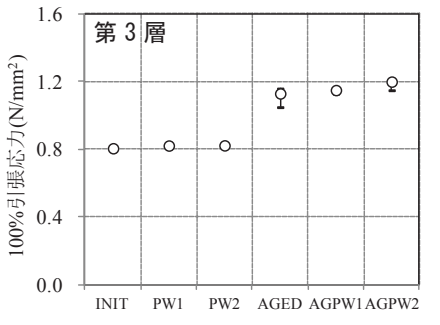

劣化条件

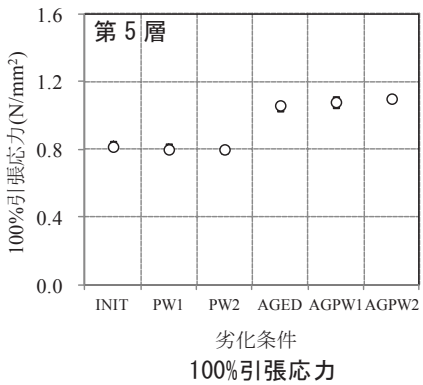

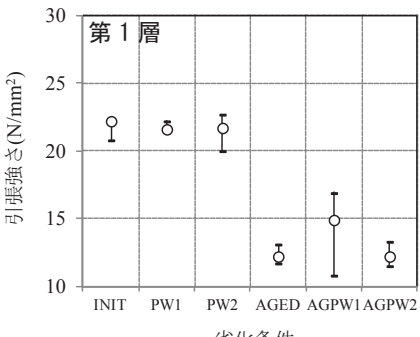

劣化条件

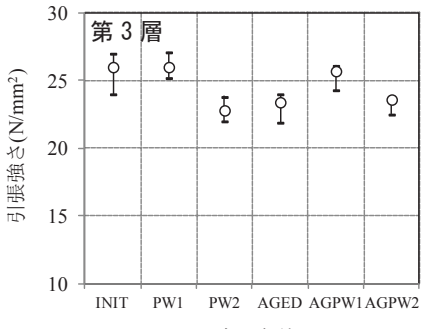

劣化条件

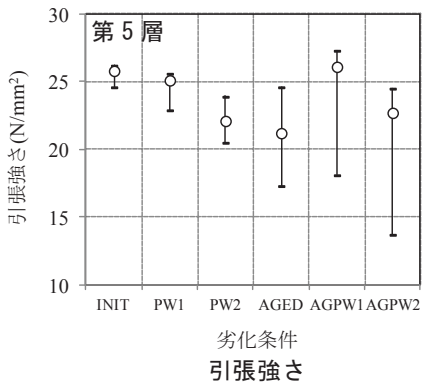

引張強さ

Fig.4 Change of mechanical properties in Rubber A due to water, oxidation and those combination
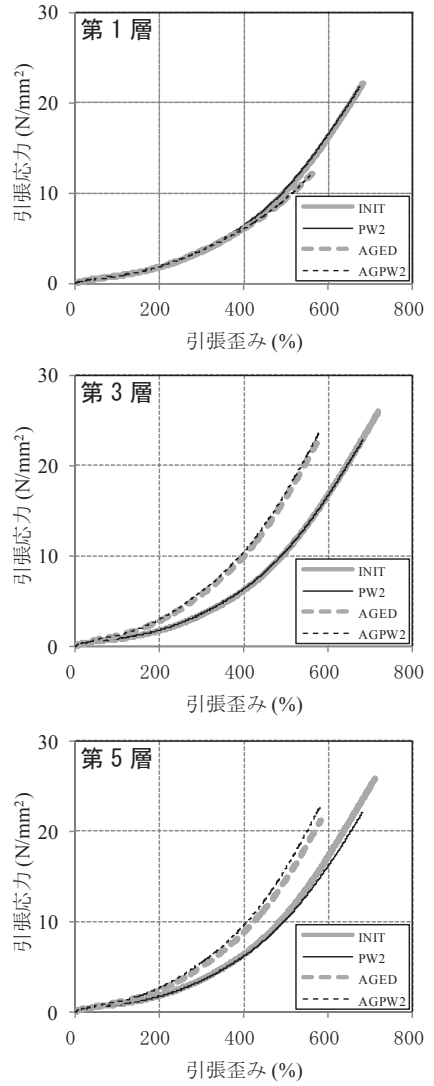

Fig.5 Change of S-S curve in Rubber A due to water etc. 
比べて大きく，劣化傾向を読み取ることは困難であった。

ダンベル試験片の引張応力ー引張歪み曲線（Stress-Strain 曲線, 以下 S-S 曲線) 初期状態 INIT, 水劣化後 PW2, 酸化劣化後 AGED および両因子の複合劣化後 AGPW 2 で比較して Fig. 5 に示す。各曲 線は同一層内の 5 本のうち, 引張強さおよび切断時伸びが中央值を 示したダンベル試験片の結果である。各層の INIT どうしを比較す ると, S-S 曲線の形状, 引張強さ, 切断時伸びの全てにおいて有意 な差が見られず，表面，内部によらず安定した物理特性を有してい る。水劣化については, 全層とも INIT と PW2 の間, AGED と AGPW2 の間にほとんど差が見られず, 水がゴムAの物理特性に及 ぼす影響はごく僅かであると考えられる。次に INIT とAGED を比 較すると, 表面と内部で大きく様相が異なっている。第 1 層では酸 化劣化による S-S 曲線の形状変化はほとんど見られないものの, 引 張強さと切断時伸びが大きく低下している。一方，第 $3 ， 5$ 層では 全歪み領域に渡って応力が大きくなり, 切断時伸びは第 1 層と同レ ベルにまで低下したものの, 引張応力は酸化劣化前とほとんど変わ らない結果となった。

塩水劣化, 酸化劣化および両因子の複合劣化による物理特性の変 化を Fig.6 に，S-S 曲線の変化を Fig.7 にそれぞれ示す。両図にお ける INIT および AGED の結果はそれぞれ Fig.4，5 と同じもので ある。評価した全ての物理特性について, 全般に水劣化と塩水劣化 との間に顕著な差異は見られなかった。

ゴム $\mathrm{A}$ の物理特性のうち 100\%引張応力について, 中央值の初期 值に対する変化率を Table 3 に示す。初期状態からの恋化率を見る と, 水劣化が塩水劣化よりも若干大きいものの, 有意な差を見出す
までには至らなかった。また, 塩水劣化 SW2 の変化率は第 1 層で $4.3 \%$ 増加, 第 3,5 層内部では $1.3 \sim 1.5 \%$ 増加に留まっており, 伊 藤ら ${ }^{6)}$ の NR ダンベル試験片に直接塩水サイクル噴霧 240 回を施し た場合の約 $20 \%$ 増加を大きく下回る結果となった。塩水に直接曝さ れることのないゴム内部は, 塩水の影響をほとんど受けないと考え られる。一方, 酸化劣化を付与した後では水劣化と塩水劣化の結果 に有意な差が現れた。AGED に対する水劣化 AGPW2 の変化率は第 1 層で $+3.7 \%$, 第 3,5 層で+4.9 +8.7\% と硬化したのに対し, AGED に対する塩水劣化 AGSW2 の変化率は第 1 層で- $1.2 \%$, 第 3,5 層内 部で-3.7〜 - $4.9 \%$ と軟化した。酸化劣化により老化防止剂が減少した ゴム $\mathrm{A}$ に塩水を噴霧した結果, 2.3 節に示したような塩化物イオン による水分吸着と劣化の相乗効果がより一層加速したことが考えら れるものの，物理特性の評価のみから判断することは困難である。

以上の結果をまとめると, ゴム $\mathrm{A}$ は水／塩水劣化の影響に比べて

Table3 Change of $100 \%$ tensile stress in Rubber A (\%)

\begin{tabular}{|c|c|c|c|c|c|c|}
\hline \multirow{2}{*}{ 層 } & \multirow{2}{*}{$\begin{array}{l}\text { 噴霧 } \\
\text { 亦件 }\end{array}$} & PW1 & PW2 & \multirow{2}{*}{ AGED } & AGPW1 & AGPW2 \\
\hline & & SW1 & SW2 & & AGSW1 & AGSW2 \\
\hline \multirow{2}{*}{ 第 1 層 } & 水 & +2.7 & +4.8 & \multirow{2}{*}{-2.4} & $-2.2(+0.2)$ & $+1.3(+3.7)$ \\
\hline & 塩水 & +1.2 & +4.3 & & $-0.4(+2.0)$ & $-3.6(-1.2)$ \\
\hline \multirow{2}{*}{ 第 3 層 } & 水 & +2.0 & +2.1 & \multirow{2}{*}{+40.2} & $+42.7(+2.5)$ & $+48.9(+8.7)$ \\
\hline & 塩水 & +0.7 & +1.5 & & $+42.7(+2.5)$ & $+36.5(-3.7)$ \\
\hline \multirow{2}{*}{ 第 5 層 } & 水 & -2.0 & -2.0 & \multirow{2}{*}{+29.9} & $+32.4(+2.5)$ & $+34.8(+4.9)$ \\
\hline & 塩水 & -0.4 & +1.3 & & $+32.4(+2.5)$ & $+25.0(-4.9)$ \\
\hline
\end{tabular}
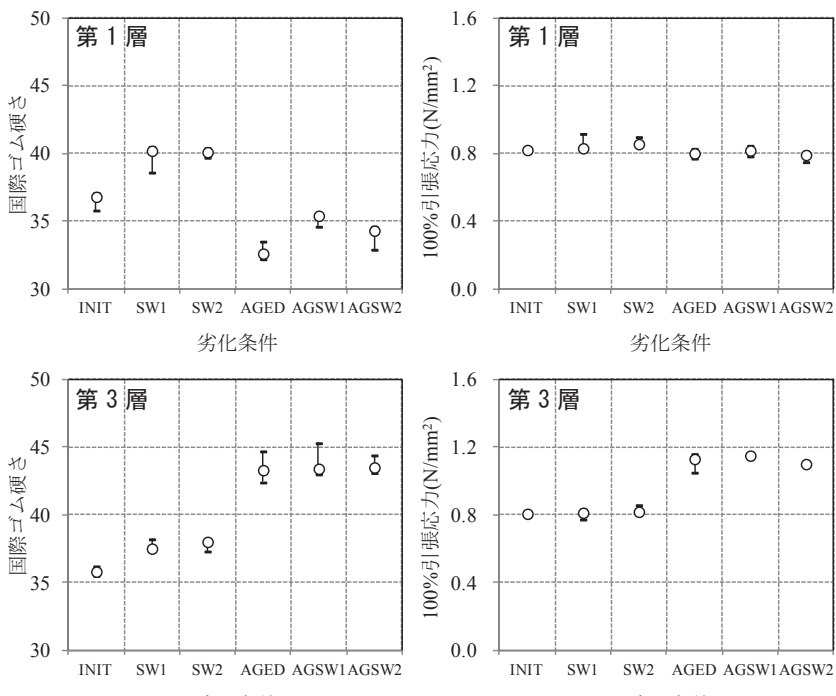

劣化条件

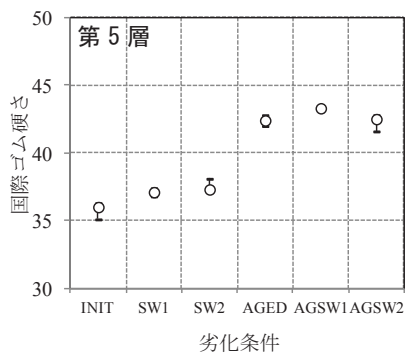

国際ゴム硬さ

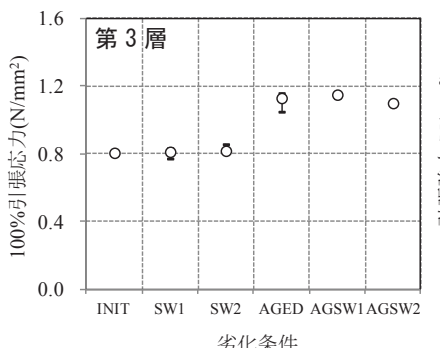

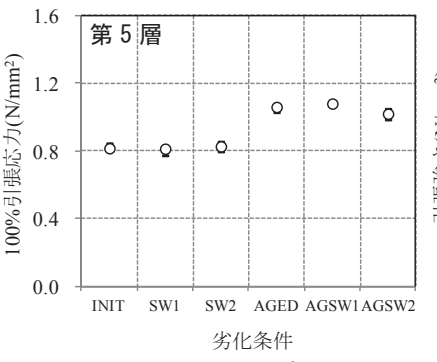

100\%引張応力
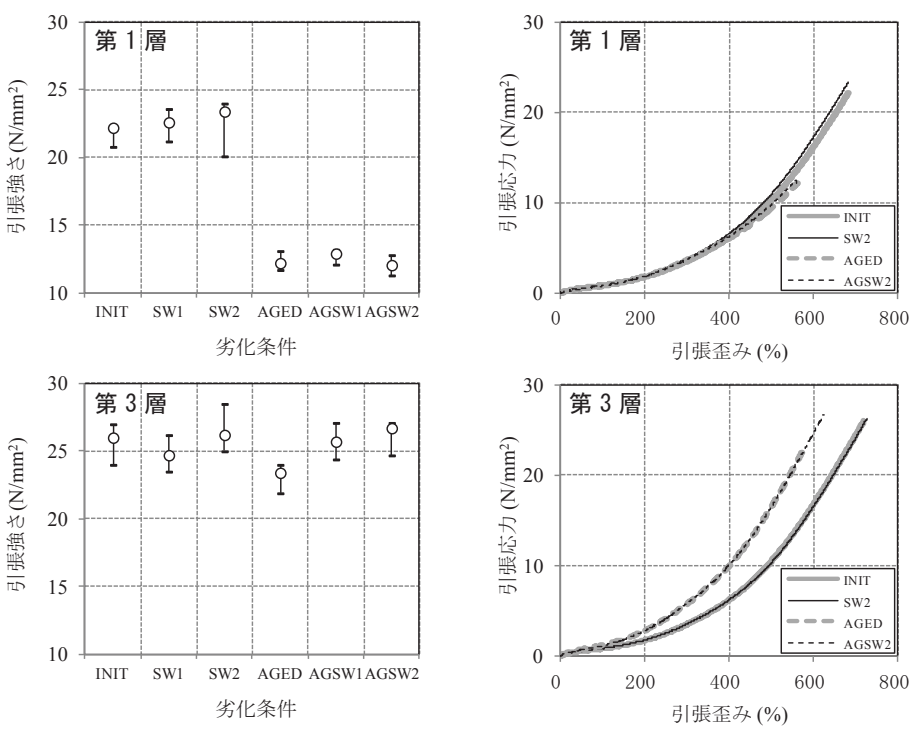

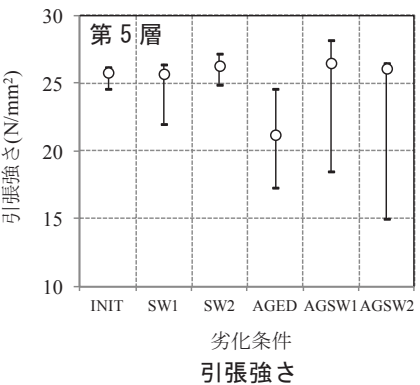

引張強さ

Fig.6 Change of mechanical properties in Rubber A due to saltwater, oxidation and those combination

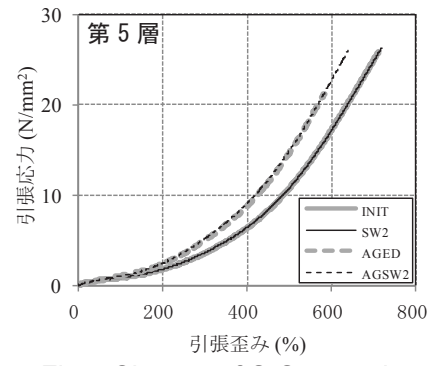

Fig.7 Change of S-S curve in

Rubber A due to saltwater etc. 
酸化劣化による物理特性の変化が顕著であった。酸化劣化によって 内部では初期值に対して大きく応力が増加した一方, 表面では僅か ながら低下寸る結果となった。一般に, NR は解重合型の劣化が進 行するゴムであり, 空気中の酸素に触れる表面では酸化劣化による 分子鎖の切断（軟化）之残留硫黄の後加硫による分子鎖の結合（硬 化）が同時に進行し, 軟化と硬化がせめぎ合う形で劣化が進行する 一方，酸素に触れることのない内部では後加硫による硬化が支配的 となるとされている 11),12)。本実験におけるゴム A の酸化劣化による 物理特性の変化は, 定性的な NR の酸化劣化特性を定量的に裏付け るものと考えられる。

\section{3 ゴム B (EPDM 系) の物理特性変化}

水劣化, 酸化劣化および両因子の複合劣化を付与したことによる 物理特性の初期值からの変化を Fig.8 に示寸。図の表記方法はゴム A と同様である。

国際ゴム硬さの初期值は表面から内部までほぼ安定した值となっ ている。水劣化を付与すると, 層によらず概数噴霧サイクル数に伴 って硬さが増し, その増加度合いは表面に近いほど大きくなった。 また, 酸化劣化を付与することにより全層で硬さが増した。第 1 層 では水劣化に比べて酸化劣化による硬化が顕著に現れたが, 表面か ら遠ざかるとともに硬化の度合いは低下していった。酸化劣化後の ゴムに水劣化を施した場合も, 概称初期状態からの水劣化による変 化と同様の傾向を示した。

100\%引張応力は初期值の層によるばらつき, 劣化付与後の同一層 内における試験片 5 本の結果のばらつきともに非常に小さく, 安定 した結果が得られた。水劣化による応力の変化については, 第 1 層
ではほとんど変化を示さないか緩やかに増加，第 3，5 層ではほと んじ変化を示さないかごく僅かに低下した。酸化劣化による変化は, 水劣化による変化に比べて非常に大きく, 特に第 1 層で顕著である。 応力の増加率は表面に近いほど大きくなっており, 応力が内部では 増加したが表面では低下したゴム A とは異なる傾向が見られる。

引張強さのばらつきはゴム $\mathrm{A}$ と比較すると小さいものの, 水劣化 付与の結果から明確な傾向を読み取ることは難しい。酸化劣化によ る引張強さの低下は表面に近いほど顕著に現れた。

初期状態および劣化付与後のダンベル試験片の $\mathrm{S}-\mathrm{S}$ 曲線を Fig.9 に示す。ゴム A と同様, 各曲線は同一条件の 5 本のうち, 引張強さ および切断時伸びが中央值を示した試験片の結果を示している。各 層の INIT どうしを比較すると, S-S 曲線の形状, 引張応力, 切断 時伸びの全てにおいて有意な差は見られず，表面，内部によらず安 定した物理特性を示している。水劣化については，全層とも INIT と PW2 の間, AGED と AGPW2の間に明確な違いは現れておらず, 水がゴム B の物理特性に及ぼす影響はごく僅かであると考えられる。 第 5 層の INIT と PW2 の間のみ若干の差が見られるものの, 水劣 化の影響によるものか個体差によるものかは判別し難い。次に INIT と AGED を比較すると, 第 5 層では酸化劣化によって全歪み領域 に渡って僅かに応力が大きくなったが，S-S 曲線の形状自体に顕著 な変化は見られない。一方，表面に近づくほど酸化劣化の影響は顕 著に現れるようになる。特に第 1 層では, S-S 曲線の形状が初期状 態の逆 $\mathrm{S}$ 字あるいは歪みとともにハードニングしていく形状から， 酸化劣化後には線形に近い形状に変化するとともに, 引張強さ, 切 断時伸びが大きく低下した。
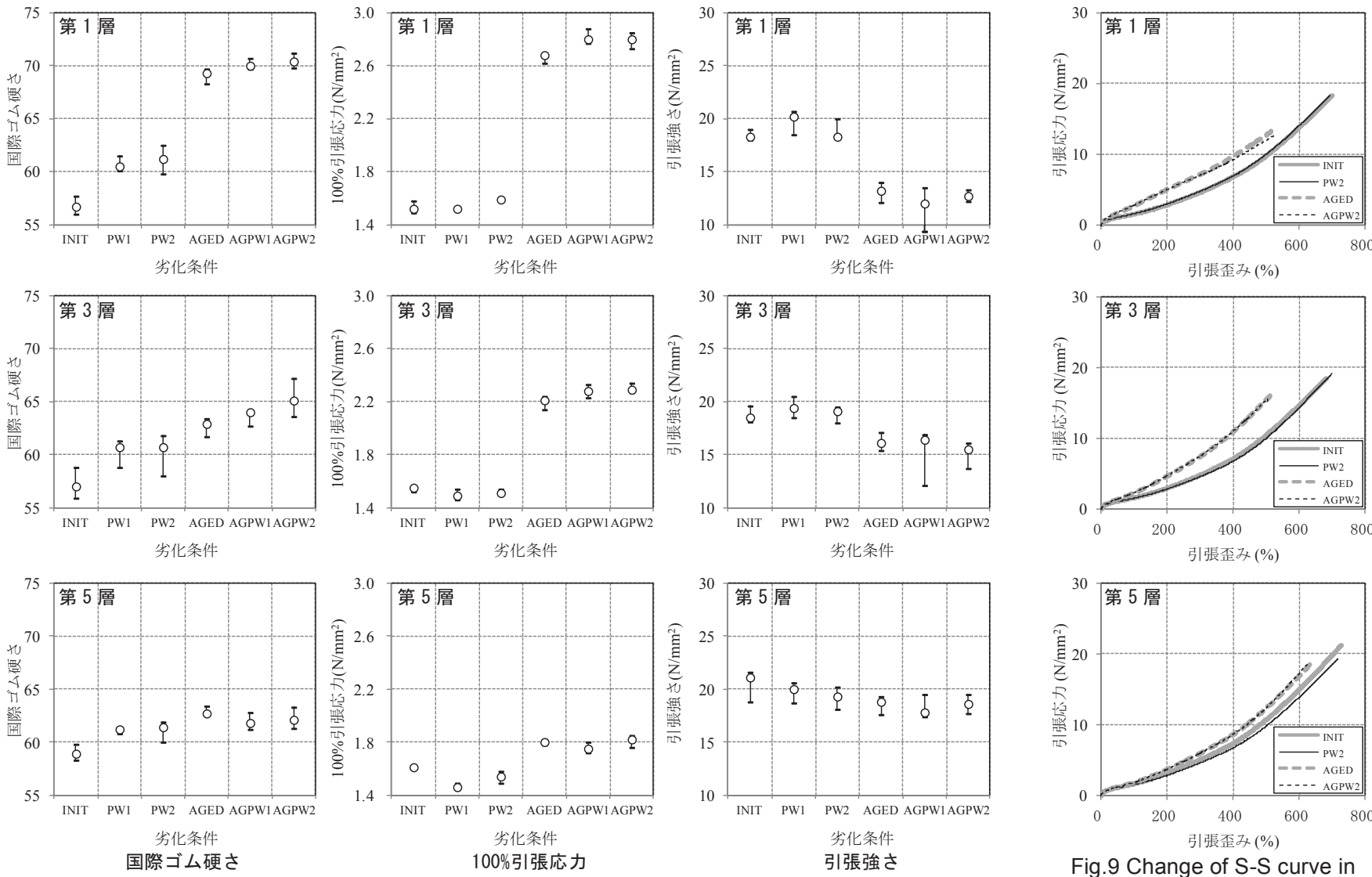

Fig. 8 Change of mechanical properties in Rubber B due to water, oxidation and those combination

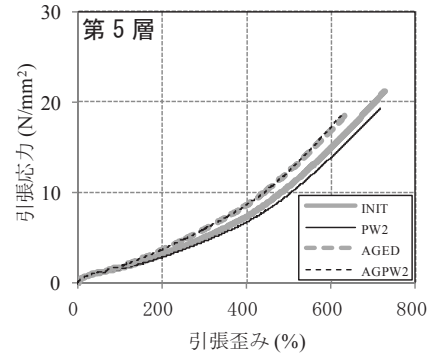

Fig. 9 Change of S-S curve in Rubber $B$ due to water etc. 
塩水劣化, 酸化劣化および両因子の複合劣化による物理特性の変 化を Fig.10 に, S-S 曲線の変化を Fig.11 にそれぞれ示す。両図に おける INIT および AGED の結果はそれぞれ Fig.8，9 と同じもの である。評価した全ての物理特性について, 全般に水劣化と塩水劣 化との間に顕著な差異は見られなかった。

ゴム B の物理特性のうち 100\%引張応力について, 中央值の初期 值に対する変化率を Table4 に示す。初期状態からの変化率につい て, 水劣化と塩水劣化に有意な差は見られない。水劣化 $\mathrm{PW} 2 /$ 塩水 劣化 SW2 後の応力は, 第 1 層で変化率 $+4.6 \% /+3.3 \%$ と増加した一 方, 第 3, 5 層では変化率-2.6〜-4.3\%/-1.3〜-6.2\%と逆に低下した が, その変化率は酸化劣化が及ぼす影響に比べればごく僅かである。 EPDM 系合成ゴムのダンベル試験片を塩水に浸漬した 7)ところ膨潤 によると考えられる軟化を生じたのに対し, 本実験では第 1 層が軟 化していない。表面に水／塩水を断続的に噴霧するのみであれば, 常時浸漬を受ける場合のような水分吸着や老化防止剂溶出による劣 化 ${ }^{9,}$ 10)が顕著に生じることはないものと推測される。

酸化劣化の付与後は, 水劣化と塩水劣化の結果に差が現れた。 AGED に対する水劣化 AGPW2 の変化率は第 1 層+7.9\%, 第 3 層 $+5.1 \%$, 第 5 層+1.2\% となった一方, AGED に対する塩水劣化 AGSW2 の変化率は第 1 層+12.5\%, 第 3 層+15.5\%, 第 5 層+8.1\% となった。どちらも表面に近いほど概ね応力が大きくなる傾向が見 られるが, その変化率は塩水劣化の方が大きい。

以上の結果をまとめると, ゴム $\mathrm{B}$ もゴム $\mathrm{A}$ と同様, 水/塩水劣化 の影響に比べて酸化劣化による応力の変化が顕著であった。ただし， 酸化劣化後のゴムに水/塩水劣化を付与したときの変化率はゴム $\mathrm{A}$
よりも大きくなった。酸化劣化の影響については, ゴム A と異なっ て応力が層によらず増加し, その変化率は表面に近いほど大きくな った。一般に EPDM は架橋型の劣化が進行するゴムであり, 酸化 劣化による分子鎖の切断, 再結合と残留硫黄の後加硫による分子鎖 の結合がともにゴムを硬化させる形で劣化が進行するとされている 11),12)。従って, 空気中から酸素が供給される表面に近いほど応力の 増加が顕著に現れる。本実験におけるゴム B の酸化劣化による物理 特性の変化は, 定性的な EPDM の酸化劣化特性を定量的に裏付け るものと考えられる。

\section{5. まとめ}

建築用積層ゴム支承の被覆ゴムとして一般的に使用されるゴム $\mathrm{A}$ （NR 系）およびゴム B（EPDM 系）について，劣化が表面から内 部に向かって一方向に進行する過程を考慮した実験方法によって酸

Table4 Change of $100 \%$ tensile stress in Rubber B (\%)

\begin{tabular}{|c|c|c|c|c|c|c|}
\hline \multirow{2}{*}{ 層 } & \multirow{2}{*}{$\begin{array}{l}\text { 噴霧 } \\
\text { 柰件 }\end{array}$} & PW1 & PW2 & \multirow{2}{*}{ AGED } & AGPW1 & AGPW2 \\
\hline & & SW1 & SW2 & & AGSW1 & AGSW2 \\
\hline \multirow{2}{*}{ 第 1 層 } & 水 & \pm 0.0 & +4.6 & \multirow{2}{*}{+76.3} & $+84.2(+7.9)$ & $+84.2(+7.9)$ \\
\hline & 塩水 & +8.6 & +3.3 & & $+89.5(+13.2)$ & $+88.8(+12.5)$ \\
\hline \multirow{2}{*}{ 第 3 層 } & 水 & -3.9 & -2.6 & \multirow{2}{*}{+42.6} & $+47.1(+4.5)$ & $+47.7(+5.1)$ \\
\hline & 塩水 & +0.6 & -1.3 & & $+48.4(+5.8)$ & $+58.1(+15.5)$ \\
\hline \multirow{2}{*}{ 第 5 層 } & 水 & -9.3 & -4.3 & \multirow{2}{*}{+11.8} & $+8.7(-3.1)$ & $+13.0(+1.2)$ \\
\hline & 塩水 & -5.6 & -6.2 & & $+11.2(-0.6)$ & $+19.9(+8.1)$ \\
\hline
\end{tabular}
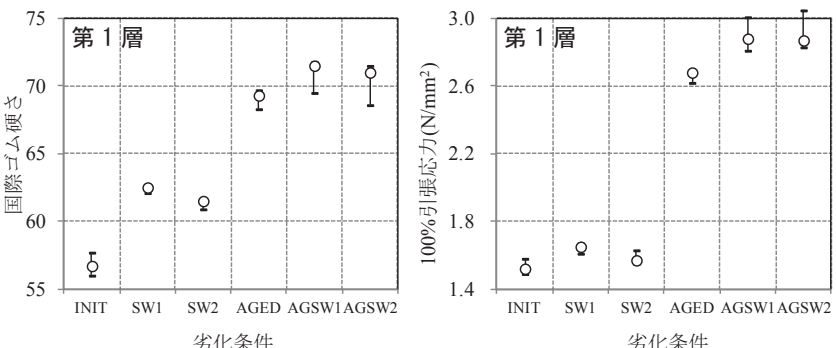

劣化条件

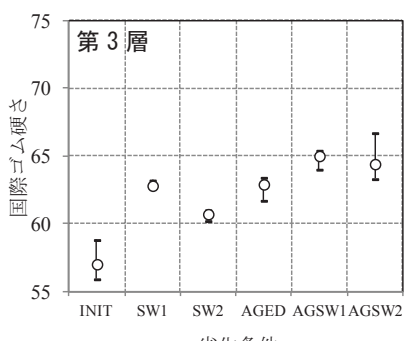

劣化条件

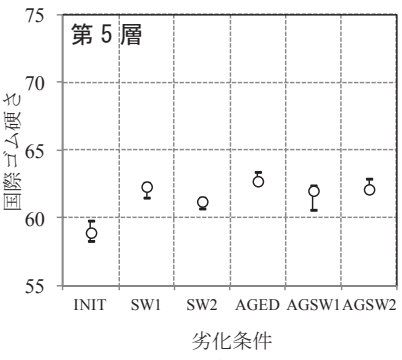

国際ゴム硬さ

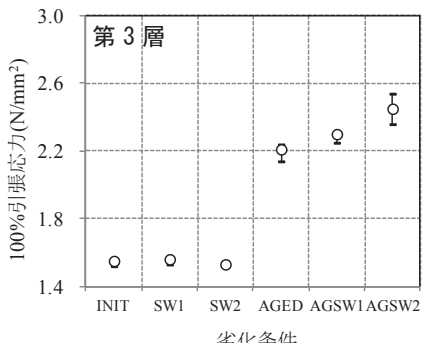

劣化条件

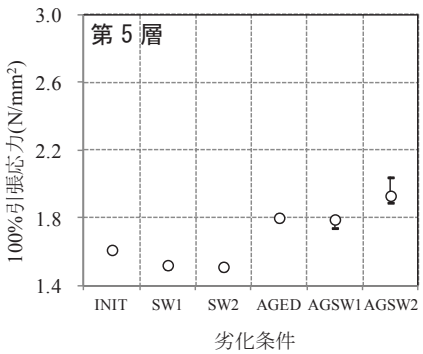

$100 \%$ 引張応力

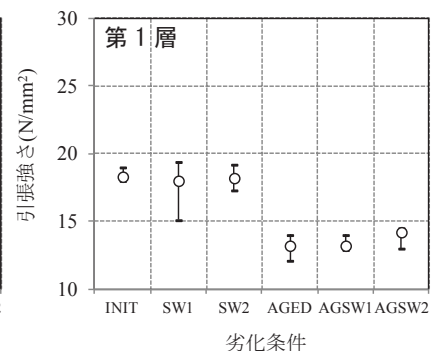

劣化条件
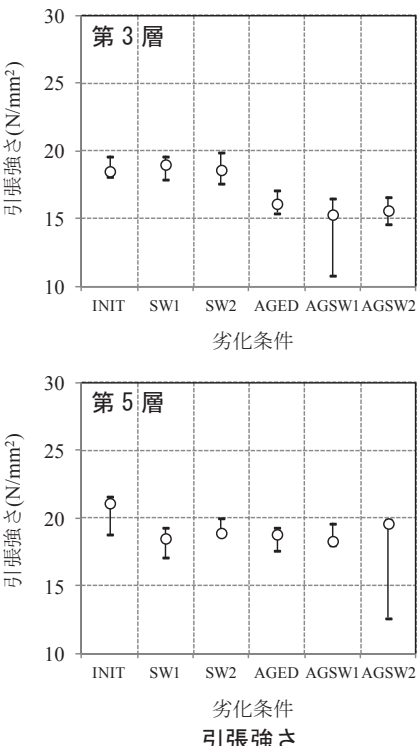

引張強さ

Fig.10 Change of mechanical properties in Rubber B due to saltwater, oxidation and those combination
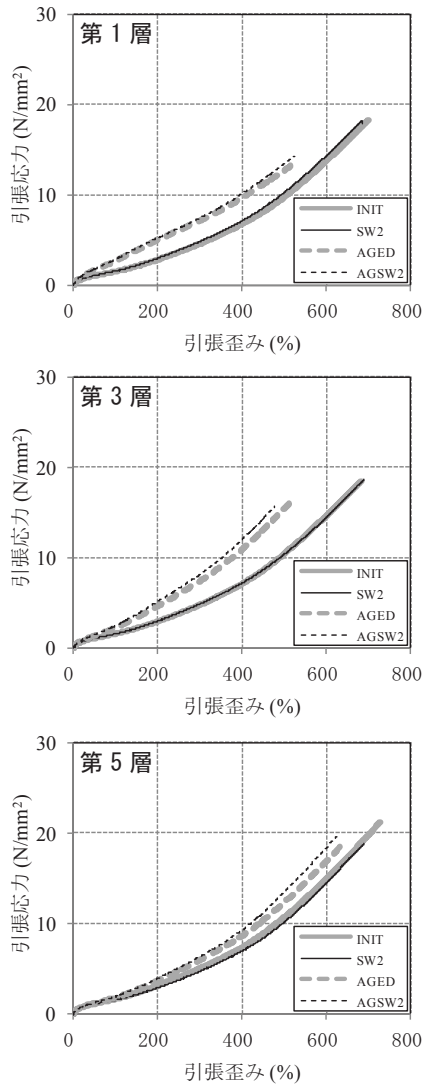

Fig.11 Change of S-S curve in

Rubber B due to saltwater etc. 
化劣化, 水 /塩水劣化, および両因子の複合劣化を付与し, 物理特 性の変化を調査した。同一層内における各物理特性值に顕著な差異 が見られないことから，ゴムブロック試験体に外部劣化因子を付与 した後に外周部および裏面を切除し, 残った部分の表面から深さ $10 \mathrm{~mm}$ までの範囲を評価対象とした本研究の実験方法は, 概ね積層 ゴム支承の形状および設置環境条件を考慮した劣化過程を模擬する ことができたものと考える。得られた知見は以下の通りである。

・ゴム A, ゴム B ともに, 物理特性に及ぼす外部劣化因子は酸素が 支配的であった。なお, ゴム内部の残留硫黄による後加硫などに 起因する分子鎖の再結合もゴムを硬化させる方向に大きな影響を 及ぼした可能性が高い。

・ 80 年相当の酸化劣化を付与したゴム A は，空気中の酸素に触れ る表面で僅かに軟化した。内部では逆に硬化し, 被覆ゴム厚に相 当する表面からの深さ $8 \sim 10 \mathrm{~mm}$ 位置における $100 \%$ 引張応力の 増加率は $30 \%$ 程度であった。

- 水/塩水劣化に対するゴム $\mathrm{A}$ の物理特性変化は小さく, 60 日間 のサイクル噴霧後も $100 \%$ 引張応力は数\%の増加に留まった。た だし, 80 年相当の酸化劣化を付与したゴム $\mathrm{A}$ に塩水劣化を施し た場合，100\%引張応力は逆に数\%低下した。これは，老化防止剤 が消費された後の空隙に塩化物イオンが浸透し, 水分吸着と劣化 の相乗効果を加速させたためであると考えられる。

・ゴム B の酸化劣化特性はゴム A と異なり, 表面に近いほど硬化の 度合いが大きくなった。 80 年相当の酸化劣化により，100\%引張 応力が表面で $80 \%$ 程度, 被覆ゴム厚に相当する $8 \sim 10 \mathrm{~mm}$ 深さ位 置で $10 \%$ 程度増加した。

・ゴム B の水 /塩水劣化に対する物理特性変化は小さく, $100 \%$ 引 張応力は数\%の増減に留まった。ただし，80 年相当の酸化劣化後 のゴム $\mathrm{B}$ に水 /塩水劣化を付与すると明確な応力の増加が見られ， 特に塩水劣化の場合にその傾向が強く現れた。

ゴム $\mathrm{A}$, ゴム $\mathrm{B}$ ともに酸化劣化による物理特性の変化率は表面と 内部で大きく異なる結果となった。酸素の浸透が両ゴム表面のごく 浅い領域に留まり, 表面部のみに大きな影響を及ぼしたためと考え られる。また，水/塩水に対しては表面部においても顕著な物理特 性変化は見られなかった。以上より,ゴム Aおよびゴム $\mathrm{B}$ は積層ゴ 厶支承を建物供用期間に渡って外部劣化因子から保護寸る役割を十 分に果たしているものと考える。

なお, NR 系や EPDM 系ゴムは概ね本研究結果と同様の傾向を示 すと考えられるが，厳密にはゴムの配合，特に硫黄配合量によって 劣化特性も異なると推察されるため, 積層ゴム支承メーカー各社が 使用する被覆ゴムについて実験データのさらなる蓄積が望まれる。

\section{謝辞}

本研究における実験の実施および結果の分析は, 一般財団法人化 学物質評価研究機構東京事業所の渡邊智子氏ならびに仲山和海氏に ご担当頂いた。また, 本論文の執筆に当たりご指導を賜った。ここ に記し，感謝の意を表する。
参考文献

1）日本建築学会：免震構造設計指針, 1989

2）渡部征男，加藤朝郎，米田玄次，広谷勉：約 40 年を経過した積層ゴムの 経年変化調査, 土木学会耐震工学委員会第 1 回免震·制震コロキウム講演 論文集，pp.439-446，1996

3）浜口弘樹，相沢覚，鮫島祐介，菊地隆志，鈴木重信，芳沢利和：約 20 年 間使用した積層ゴムの経年変化調査, 日本建築学会技術報告集 15,30 , pp.393-398, 2009.6

4）日本ゴム協会: 設計者のための免震用積層ゴムハンドブック, 理工図書, 2000

5）日本ゴム協会: 免震用積層ゴム委員会技術報告 免震建築用積層ゴムと環 境・耐久性, 2006

6）伊藤義人，矢澤晃夫，佐藤和也，顧浩声，忽那幸浩，山本吉久：橋梁支 承用ゴムの環境劣化特性に関する基礎的研究, 土木学会論文集 No.794, pp.253-266, 2005.7

7）株ブリヂストン：技術資料 積層ゴムの耐久性能について，2009.10

8）田中享二, 宋炳昌, 小池迪夫 : 建築用ゴム系材料の変動するオゾン濃度 下での劣化の評価, 日本建築学会構造系論文報告集第 428 号, pp.47-53, 1991.10

9）山田美緒, 杉岡佳彦, 進博人, 天野良三, 大武義人:水道水における EPDM の老化防止剂の溶出挙動とゴム劣化評価, 日本ゴム協会誌 Vol.81No.2, pp.44-50, 2008.2

10）中村勉，河原成元，大武義人，市川憲良：合成ゴムの水道水による劣化 について EPDM パッキンの残留塩素による劣化メカニズム, 日本建築学 会大会学術講演梗概集 D1, pp.587-588, 2010.9

11）大武義人：高分子材料の事故原因究明と PL 法，アグネ技術センター, 1999

12）深堀美英：設計のための高分子の力学，技報堂，2000 


\title{
AN EXPERIMENTAL STUDY ON DURABILITY OF COVERING RUBBER APPLIED TO RUBBER BEARINGS
}

- Change of mechanical properties -

\author{
Hiroki HAMAGUCHI*, Tamotsu HASEGAWA** and Yoshito OHTAKE*** \\ * Structural Dynamics Group Leader, Research and Development Institute, Takenaka Corporation, M.Eng. \\ ** Chief Researcher, Research and Development Institute, Takenaka Corporation \\ *** General Manager, Polymer Technology Center, Chemicals Evaluation and Research Institute, Japan, Dr.Eng.
}

Durability or weather resistance is one of the biggest concerns about isolation rubber bearings. Since rubber material is thought to be less durable than other structural materials such as concrete and steel, several investigations about the durability of rubber materials actually used for structural members of bridges and buildings for several decades to one century have been conducted. Those results show that mechanical properties of surface part of the rubber materials have been changed to a certain degree, by being exposed to some deterioration factors such as oxygen, ozone, ultraviolet rays and water, and those of inner part are assumed to keep almost the same as those in the initial condition. Hence, covering rubber or surface rubber has an important role for rubber bearings to keep their mechanical properties less changed for an expected long life span.

In this paper, aging effects of oxygen, water / saltwater and the combination of oxygen and water / saltwater on mechanical properties of two types of covering rubbers actually used for rubber bearings were experimentally studied. Rubber A (natural rubber, NR) and Rubber B (complex of NR and Ethylene-Propylene-Diene terpolymer, EPDM) were selected for test materials. Accelerated aging test corresponding to 80 years, water / saltwater cyclic spray test for $30 / 60$ days, and the serial testing of the above two tests were conducted for the both rubber materials. Considering the configuration of rubber bearings and the environmental condition of isolation levels, it is evident that deterioration factors affect only in one direction from the surface to the inside of rubber bearings. Therefore, rubber blocks, not dumbbell specimens, were chosen and exposed to the above deterioration factors. After the deterioration, rubber blocks were sliced and cut into dumbbell test specimens, disposing the peripheral part and the back side, to remove the deterioration effects from the side and the back of the rubber blocks. Finally, hardness and tensile properties such as $100 \%$ tensile stress and tensile strength were measured for each dumbbell specimen.

Test results showed that oxidative deterioration affected the mechanical properties of the both specimens much greater than water / saltwater deterioration. Also it became clear that oxidative deterioration had a complicated effect on the changes in the mechanical properties of Rubber A due to the depolymerization characteristics of NR, while Rubber B simply became harder with the progress of oxidation, due to the cross linking characteristics of EPDM. Since $100 \%$ tensile stress of deteriorated specimens showed only 1.1 to 1.3 times larger values than the initial values at the depth of 8 to $10 \mathrm{~mm}$ from the surface, which corresponded to the thickness of covering rubber, it was concluded that covering rubbers were able to protect rubber bearings from deterioration factors such as oxygen and water / saltwater for an expected life span of isolation buildings. 